stand gebleven waren, en de noordelijker gelegen streek van het Buginese Soppeng, waar uit een messianistische stroming een groep christenen voortkwam die zelfs gedurende de Japanse tijd groeide.

Ook de bij dit zendingswerk betrokken kerkelijke en zendingsorganisaties vertoonden een divers en complex patroon. Er waren velerlei instanties en personen uit de protestantse of Indische kerk, de gereformeerde kerken en de hervormde kerk, die in wisselende combinaties en in goede of minder goede harmonie samenwerkten en leiding gaven. De Jong wijdt een apart hoofdstuk aan hun veelzijdige en vaak moeizame arbeid.

Het is van bijzonder belang dat hij bovendien uitgebreid aandacht besteedt aan de religieuze en sociale context van deze nieuwe christengroepen en aan de wijze waarop zij invloed bleven vertonen van de samenleving waaruit zij voortkwamen. Hij geeft karakteristieken van uit de islam ontstane religieuze bewegingen en door de islam beïnvloede voorbeelden van traditionele religie, waarmee de zending in aanraking kwam. Daarbij weet hij ook op eigen onderzoek steunende bijdragen te leveren aan de kennis van deze nog nauwelijks bestudeerde groeperingen. Zo verschaft hij materiaal over de leer van de Mukhdi Akbar en laat hij zien waarom de aanhangers daarvan zich verheven voelden boven zowel de islam als het christendom, maar toen de Indonesische overheid hun beweging niet als een aparte religieuze stroming erkende en daarom verbood, zich voornamelijk uit sociale motieven niet meer tot de islam wendden maar (voor zolang als onvermijdelijk zou zijn) tot het christendom overgingen.

In enkele slotopmerkingen schetst de auteur de ontwikkeling van deze jonge kerk sinds 1966. Hij constateert dat er qua integratie in de samenleving en qua aantal nauwelijks van werkelijke groei te spreken is. Het is nooit om meer dan enkele duizenden personen gegaan, van wie een toenemend aantal bestaat uit van elders gekomen Indonesiërs. Het is te begrijpen dat hij een onzekere toekomst voorziet.

Zijn jarenlange verblijf terplaatse als docent kerkgeschiedenis aan de theologische hogeschool heeft de auteur in staat gesteld zijn studie speciaal te baseren op lokale kerkarchieven, die aan te vullen met interviews, en te larderen met citaten in de Indonesische en (zij het niet altijd foutloos) de Buginese of Makassaarse taal. Uit zijn bronnen geeft hij tenslotte een groot aantal karakteristieke fragmenten ter illustratie van zijn verhaal.

Aanmerkingen betreffen kleinigheden, zoals het vasthouden aan de volstrekt overbodige spelling met $\mathrm{E}$ in Buginese woorden en de aanduiding van de Ahmadiya als een tareqat (24).

Er zijn onontbeerlijke registers, een minimaal aantal drukfouten (bijvoorbeeld Pantai voor Patani, 28) en relevante illustraties. Het boek is een waardevolle, goedverzorgde beschrijving van een klein stukje zendingsgeschiedenis geworden.

J. Noorduyn

A. Klijn, Arbeiders- of volkspartij. Een vergelijkende studie van het Belgisch en Nederlands socialisme 1933-1946 (Dissertatie Groningen s. a.; Maastricht: Universitaire Pers Maastricht, 1990, 285 blz., f37,50, BF750,-, ISBN 905278006 4).

'De Belgische Werklieden Partij en de Sociaal Democratische Arbeiders Partij waren in de negentiende eeuw ontstaan en als negentiende-eeuwse partijen gingen zij ervan uit dat zij zich op een politieke theorie moesten baseren'. Dat is de eerste zin van de slotbeschouwing van deze dissertatie en het is de lezer dan inmiddels duidelijk geworden welke betekenis een dergelijke zet kan krijgen in het intellectuele schaakspel dat de schrijfster voor ons op het bord heeft gezet. De socialistische ideologie had immers in belangrijke mate gefunctioneerd als mobiliserende 
theorie onder de arbeiders. Op grond van een groeiende, georganiseerde macht was een groot aantal praktische verbeteringen ingevoerd, maar tegelijkertijd werd in de twintigste eeuw steeds duidelijker dat de theorie tekort schoot ('de theorie ging aan het succes van de beweging ten onder'). Want al gingen beide partijen nog formeel uit van het revolutionaire marxisme, in de praktijk voerden zij een reformistische politiek. Deze ambivalentie werd steeds meer als frustrerend ervaren, vooral toen de sociaal-democraten in de jaren dertig voor fundamentele vragen werden gesteld: wat te doen aan de economische crisis, hoe te reageren op het fascisme.

De meest belangrijke invloed op het debat werd uitgeoefend door Hendrik de Man met zijn 'planisme', dat theoretisch gesproken afscheid nam van het 'wetenschappelijk socialisme' en zich richtte op een verhoging van het ethisch gehalte van de beweging om daarmee ook weer dichter bij het revolutionaire ideaal te komen (en een kamermeerderheid te behalen). Dit sprak meer aan in Nederland dan in België, juist omdat de SDAP (die in de Duitse zusterpartij haar grote voorbeeld zag) zich steiler aan Marx had gehouden, maar ook omdat de groei van de beweging op een $20 \%$ bleef hangen en verdere uitbreiding alleen te bereiken was als de partij zich omvormde van arbeiders- tot volkspartij. Dat verklaart waarom het Nederlandse Plan van de Arbeid beter was dan het Belgische origineel, maar ook dat het partijprogramma in 1937 reeds fundamenteel vernieuwd was. In België echter kreeg De Man met steeds taaier tegenstand te maken, al was het maar omdat de BWP een veel omvangrijker linkervleugel had die de leiding dacht te verliezen bij de omvorming naar een volkspartij. De wonderlijke avonturen van De Man bij het uitbreken van de oorlog brachten hem definitief in diskrediet. Daarop ving een zeer verward debat aan, waarbij ook het Franse personalisme (dat overeenkomsten had met het denken van De Man) aan de orde kwam. Aangezien de partij tijdens de oorlog door een nieuwe laag jeugdige socialisten in stand was gehouden, kon de discussie echter nog tijdens de oorlogsjaren min of meer worden afgerond: het leek de Belgische socialisten het beste de oude beginselen (verklaring van Quaregnon) te handhaven, ook al besloot men van naam te veranderen (Belgische Socialistische Partij) en de formele band met tal van socialistische organisaties door te snijden (door over te gaan van collectief op individueel lidmaatschap). De terugkeer van oudere partijleiders uit Londen veranderde daar niets aan (zeker ook gezien het feit dat de Koningskwestie gesloten gelederen vergde). Tegelijkertijd werd een zeer praktisch programma van eisen geformuleerd voor de onmiddellijke toekomst. Hierdoor bleef de spanning bestaan tussen reformistische praktijk en oude theoretische retoriek. Dit alles leverde na de oorlog nauwelijks electorale winst op (iets meer dan 30\% van de stemmen), als ook een mooi symbolisch houvast in een lange traditie, wat goed was voor een sterk zelfbewustzijn.

De ontwikkeling in Nederland liep anders. Het debat verliep tijdens de oorlogsjaren zonder enige sturing vanuit de partijtop, zodat over de kracht van de verschillende stromingen in die discussie niet veel te zeggen viel. Wellicht daardoor kregen de intellectuelen die zich in het personalisme vonden ook zo overmatig veel ruimte en aandacht. Hoe dit ook zij, dit gedachtengoed leek ook zeer geschikt om de omschakeling naar een volkspartij, die in 1937 was ingezet, door te zetten, juist omdat een dergelijke doorbraak (in tegenstelling tot België) vooral aan de rechterzijde moest worden gevonden. Zoals we weten leidde dit tot niet veel meer dan de omvorming van de SDAP tot een Partij van de Arbeid; daarna werd niet veel meer van doorbraak of personalisme vernomen.

Dit geheel is een interessante dissertatie geworden. De schrijfster heeft zowel een helder overzicht gegeven over de discussies in België en Nederland, waarbij de vergelijking vooral benut is om de analyse van de ontwikkelingen in beide landen te verscherpen. Van grote waarde is ook haar periodisering, aangezien ze daardoor aannemelijk heeft kunnen maken dat het transformatiedebat van de sociaal-democratische partijen in beide landen één geheel vormt 
tussen 1933 en 1946. Aangenaam, tenslotte, is de kalme, zo niet koele toon waarop ze de discussies volgt en samenvat. Zij kan het ook niet helpen dat het al met al een ontmoedigend verhaal is geworden: juist de partijen die de pretentie hadden te beschikken over een 'wetenschappelijk' uitgangspunt werden gekenmerkt door even vage als chaotische discussies. Er was slechts een vaag verband tussen theorie en praktijk (de linkerhand wilde niet weten wat de rechterhand deed). Toch beginnen hier enige aarzelingen over de verdere implicaties van deze dissertatie, ten dele ook opgeroepen door de allerlaatste pagina's waarin de schrijfster lijkt te betwijfelen of de lezer nog enige waardering kan opbrengen voor de betrokken partijen. Haar twijfel is vooreen deel ook het resultaat van eigen werk, namelijk de keuze voorde theorie (dan wel geloof of retoriek) als analyseniveau. Welke partij zij ook onderzocht zou hebben in de recente geschiedenis: overal zou ze een vergelijkbaar beeld van chaos, verwarring, onzin en inconsistentie aantreffen. Politiek is nu eenmaal — anders dan partijleiders gewend zijn voor te stellen en intellectuelen geneigd zijn te geloven - maar zeer ten dele een intellectuele bezigheid. Dit proefschrift over het theoretisch debat is dan ook niet meer en niet minder dan een bijdrage aan de politieke geschiedenis van twee sociaal-democratische partijen, waarvan overigens de een het eindelijk gelukt is het isolement waarin het zeker een decennium te lang door de katholieken werd gehouden te doorbreken (en al die flauwekul van Banning en Vorrink was daarvoor nodig) en de ander als eerste sociaal-democratische partij in West-Europa een helder programma ontwikkelde ter bestrijding van de crisis. Een niet geringe prestatie op de misschien wel belangrijkste toetssteen van een politieke partij: effectiviteit.

P. de Rooy

\section{J.Grandia, De arbeider-wethouder Dries van der Vlerk. Een leven van dienst aan de gemeenschap} (Amsterdam: Stichting beheer IISG, 1990, 376 blz., f48,-, ISBN 906861051 1).

In deze biografie beschrijft Jan Grandia, die kort voor de publikatie van zijn studie overleed, het leven van 'arbeider-wethouder' Dries van der Vlerk (1903-1981) die opklom van eenvoudig leerling-electricièn tot wethouder te Rotterdam voor respectievelijk de post van volksgezondheid en die van onderwijs en volksontwikkeling in de jaren 1945 tot 1962. Deze carrière is nauw verbonden met de participatie van beschrevene in talrijke sociaal-democratische organisaties. Natuurlijk in SDAP/PvdA - Van der Vlerk maakte twintig jaar lang deel uit van de Partijraad van de PvdA - ; voorts in de AJC; het 'Instituut voor Arbeiders Ontwikkeling'; de VARA en enkele andere organisaties. Van der Vlerks levensloop is een fraai voorbeeld van de sociale stijgingsmogelijkheden van een (voormalig) arbeider binnen de sociaal-democratische partijorganisatie. Tevens zien we in zijn persoon de wassende invloed van het gezindheids- en cultuursocialisme weerspiegeld, zoals dat binnen SDAP en AJC tot uiting kwam. Van der Vlerk was een overtuigd cultuur-socialist, die na verzetsactiviteiten in de tweede wereldoorlog tot het christen-socialisme overging. Daarnaast is Van der Vlerks leven expressie van de integratie der sociaal-democratie binnen een 'sociaal kapitalisme', dat mede dankzij de strijd van de beweging tot stand zou komen.

Het had voor de hand gelegen beschrijving en interpretatie van Van der Vlerks leven te plaatsen binnen het kader van bovenvermelde 'Leitmotive'. Helaas is dit slechts zeer ten dele gebeurd. Grandia's studie concentreert zich toch vooral op een gedetailleerde weergave van het feitelijk verloop van Van der Vlerks politieke- en privé-leven. Behulpzaam daarbij is ongetwijfeld het feit, dat de auteur decennia lang bevriend was met het gezin Van der Vlerk en als Rotterdams ambtenaar jarenlang met wethouder Van der Vlerk samenwerkte. We mogen vanuit deze 